This is the Accepted Manuscript of the conference paper:

"Mansir I., Bouchaou L., Choukr-allah R., Chebli B., El Otmani M. (2018) Groundwater Resources Scarcity in Souss-Massa Region and Alternative Solutions for Sustainable Agricultural Development. In: Calvache M., Duque C., Pulido-Velazquez D. (eds) Groundwater and Global Change in the Western Mediterranean Area. Environmental Earth Sciences. Springer, Cham" published by Springer on 28 October 2017, DOI: 10.1007/978-3-319-69356-9_22, available online: https://link.springer.com/chapter/10.1007\%2F978-3-319-69356-9 22.

This Accepted Manuscript version is subjected to Springer Nature terms for reuse that can be found at: http://www.nature.com/authors/policies/license.html\#terms

http://www.springer.com/gp/open-access/authors-rights/aam-terms-v1 


\title{
Groundwater Resources Scarcity in Souss-Massa Region and Alternative Solutions for Sustainable Agricultural Development
}

\author{
I. Mansir, L. Bouchaou, R. Choukr-allah, B. Chebli and M. El Otmani
}

\begin{abstract}
The Souss-Massa region, located in the south-west of Morocco, is among the regions that suffer the most from water stress. It's characterized by an arid climate with low and irregular rainfall in time and space. Consequently, there's a considerable rainfall deficit which negatively affects the water resources in the region. Moreover, the economy of the region is mainly based on agriculture which consumes more than $90 \%$ of the region's total water resources. As a result, surface water resources have become increasingly insufficient with regard to the demand. Use of groundwater resources has always been a secular practice in the area. In recent years, groundwater overexploitation has exceeded the renewable resources and has led to the depletion of the different aquifers of Souss-Massa region. In addition, high population growth, degradation of water quality, expansion of agricultural and industrial activity negatively affected water availability. Furthermore, a significant proportion of raw industrial and urban water rejections are released directly into nature, and excessive use of pesticides in agriculture and marine intrusion cause pollution and salinity of the groundwater.

This study focuses on the vulnerability of groundwater resources and alternative solutions for agricultural development. This thematic allows the use of unconventional waters to test new techniques for the treatment and recycling of wastewater. Treated wastewater will be reused for irrigation in the Souss-Massa region, in order to reduce the vulnerability of water resources scarcity, to improve economic growth, to promote sustainable use of treated wastewater in agriculture and to produce good quality agricultural products.
\end{abstract}

Key words: Groundwater, Overexploitation, Pollution, Vulnerability, Wastewater

\author{
I. Mansir (\&) B. Chebli \\ Laboratory of Mechanics, Processes Energy and Environment, National School of Applied Sciences, BP \\ 1136, Agadir, Morocco \\ e-mail: iman.mansir@gmail.com \\ L. Bouchaou \\ Laboratory of Geology and Geo-Environment, Faculty of Sciences, Ibn Zohr University, BP 8106, Agadir, \\ Morocco \\ R. Choukr-allah M. El Otmani \\ Laboratory of Salinity and Plant Nutrition, Hassan II Institute of Agronomy and Veterinary Medicine, BP \\ 773, Agadir, Morocco
}




\section{Introduction}

The world will have to face a global water deficit of $40 \%$ by 2030 , write experts from the United Nations World Water Assessment Program. Three-quarters of the Arab countries inhabitants live below the water scarcity threshold of $1000 \mathrm{~m}^{3} /$ year, and almost half are in an extreme situation with less than $500 \mathrm{~m}^{3} /$ year in Egypt and Libya in particular. Not only the undeveloped countries are affected. The West American, some provinces of China, Mexico, Southeast Australia, India and the Southern Mediterranean also suffer from water stress (WWDR 2016). As for Morocco, it faces a water shortage linked to an increased drought in the last two decades. If Moroccan population growth continues, consumption will have to be reduces from $830 \mathrm{~m}^{3} /$ capita/year in 1990 to 411 $\mathrm{m}^{3}$ /capita/year in 2020 (ABHSM 2006).

The hydrological basin of Souss-Massa suffers from depletion of its water resources. Pressures on the available water resources due to the irrigated agricultural land expansion, urban and industrial growth have led to the overexploitation of groundwater. The decline rhythm of the water table is increasing at a worrying rate. Moreover, this situation is exacerbated by the long and severe droughts and the certain risks of the water quality deterioration linked to the anthropogenic activities (Malki et al. 2016) and to the marine intrusion observed in several places of the coastal areas (Tagma et al. 2009). Reducing quantities and degrading water quality in the Souss-Massa region is expected to become more acute in the near future. Therefore, the use of non-conventional waters has become a necessity. The aim of this study is to summarize the causes and effects of groundwater vulnerability, their impact on the agricultural and socio-economic sectors and some solutions to reduce water crisis in the area.

\section{Study area}

The Souss-Massa region is located in southern-west of Morocco (Fig. 1). This zone is characterized by a semi-arid to sub-desert climate. Rainfall in the region shows great spatial and temporal variability, with an average of 250 to $300 \mathrm{~mm} /$ year in the plain and about 500 to $600 \mathrm{~mm} /$ year in the mountains (Bouchaou et al. 2012). Temperatures are warm; the annual average can reach up to $20^{\circ} \mathrm{C}$. Agriculture is a strategic sector for the economy in the Souss-Massa region. It employs more than $51 \%$ of the working population and contributes to $13 \%$ of the regional Gross Domestic Product (GDP). Although, this region is intensively cultivated and ensures a leading position at national level, especially in the production of citrus and vegetables (more than 50\% of the national export volume) (Haddouch et al. 2016). In regards to water resources, Souss-Massa region has made enormous efforts to save water. Groundwater is obtained from Souss, Chtouka and Tiznit aquifers (Fig. 1). The hydrogeological basin of the Souss is the most important in southern Morocco. In addition, the large-scale hydraulic works carried out allow the exploitation of surface water resources for irrigation, the supply of drinking water to agglomerations in Agadir and the artificial recharge of the Souss aquifer. 


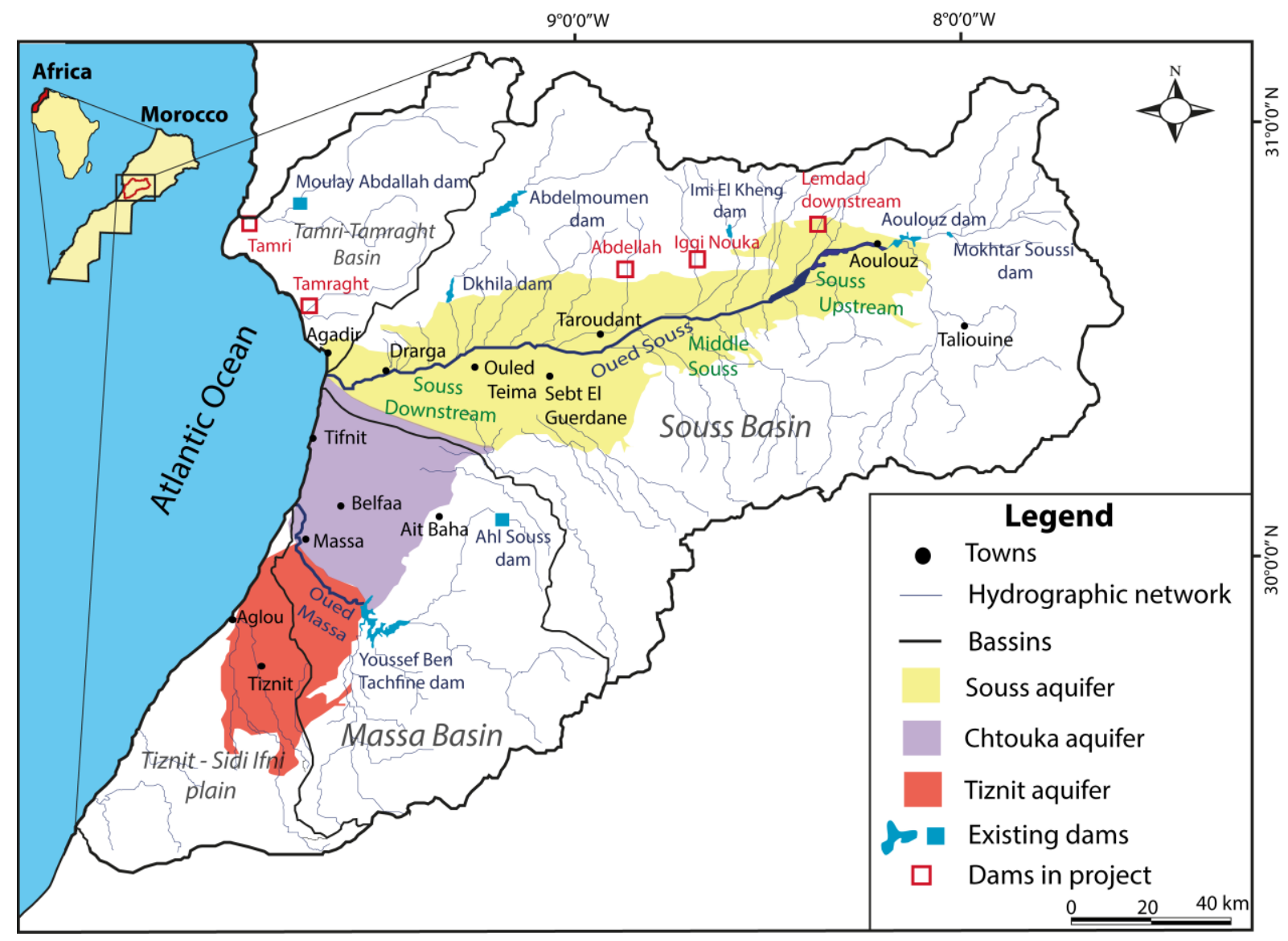

Fig. 1 Souss-Massa region

\section{Methodology}

In order to assess the vulnerability of groundwater to over-exploitation and pollution in the Souss-Massa region, several studies have been carried out. For that, we used the data collected from the Souss-Massa hydraulic basin agency and from Laboratory of Geology and Geo-environment (LAGAGE) of Ibn Zohr University (Seif-Ennasr et al. 2016 and Malki et al. 2016). Annual sampling campaigns, piezometric level calculations, physicochemical and bacteriological analyses were carried out at the level of the SoussMassa hydraulic basins in order to monitor the quality and quantity of water. The groundwater are subjected to several analyzes (electrical conductivity, Chloride, Nitrate, Ammonia nitrogen, fecal coliforms and oxidizable matters). Using these data, we were able to draw groundwater quality assessment maps as well as curves to assess the piezometric level of water tables.

\section{Results}

\subsection{Groundwater variation (quantitative aspect)}


The piezometers monitoring in the Souss-Massa plain allow us to study the evolution of the water level in different parts of the aquifers (Fig. 2a). Souss upstream shows a gradual and accentuated depletion since 2000s. The return of normal precipitation at the end of 2011 resulted in a relative increase in groundwater level (Fig. 2b). From 2013, a sharp drop was observed. The influence of intensive pumping and the lack of precipitation would explain this decline. In the Middle Souss, the decrease was moderate in the early 2000s which can be explained by the supply of irrigation water by Abdelmoumen dam and also it is due to the change in the irrigation system from gravity irrigation to drip irrigation, which means an optimization of the groundwater consumption. In the Souss downstream, the groundwater level declined in a rapid way during 2005. In 2011, the groundwater level increased due to the significant precipitation in the region. Within irrigated areas in the southern sector of Chtouka, piezometers generally show small variations. The irrigation return flow (IRF) supplied by Youssef Ben Tachfine dam maintains the water table level in this area.

It should be pointed out that more than 25000 boreholes have been drilled in the Souss-Massa basin. Most of them correspond to irrigation wells. The groundwater remains largely overexploited due to the succession of drought years and the extending of irrigated areas. This has affected the quantity and the quality of the water resources which became vulnerable to pollution. 
(a)
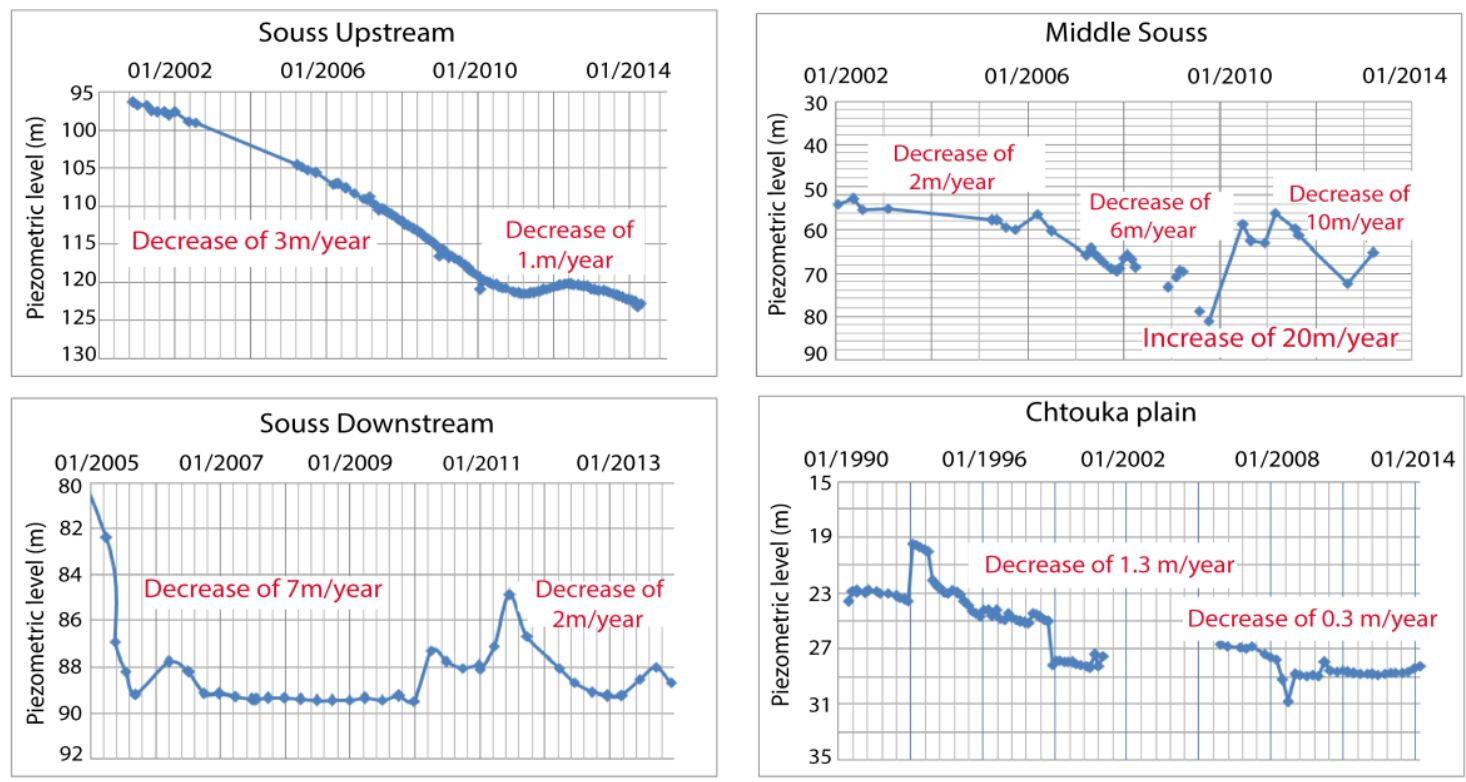

(b)

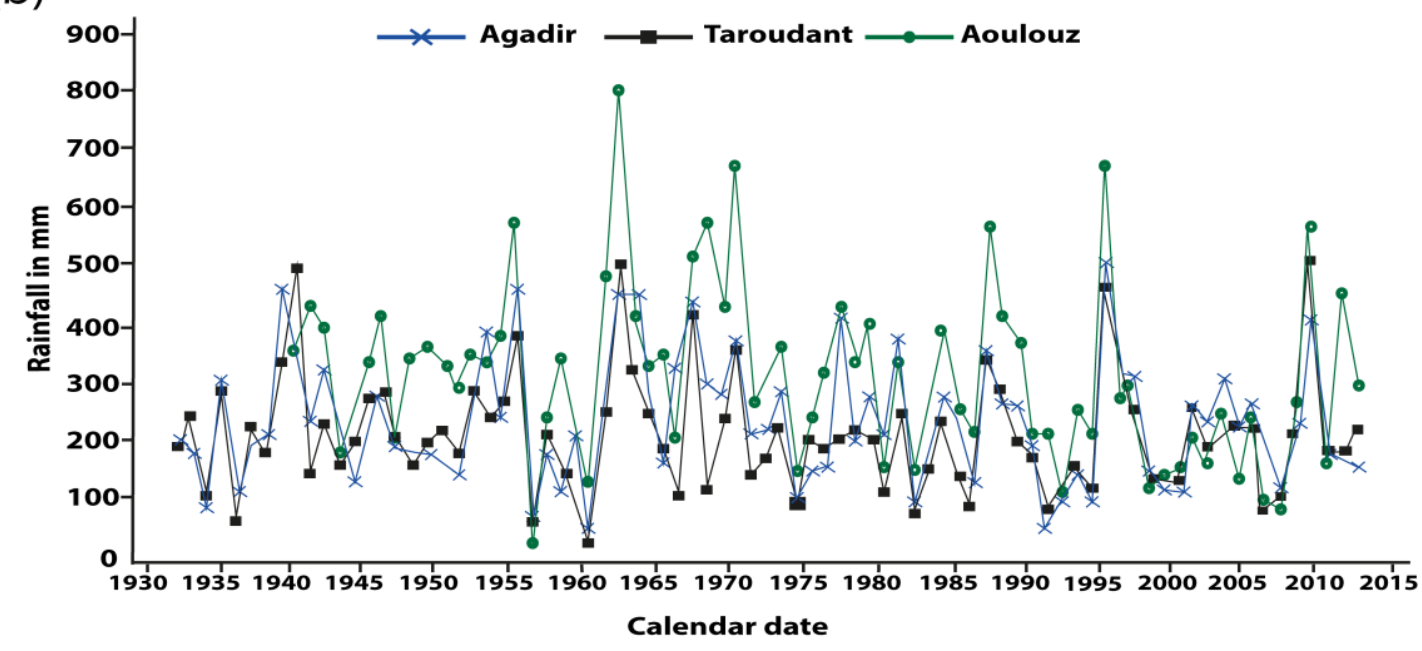

Fig. 2 Piezometric level of the aquifers and precipitation in Souss-Massa region: a Piezometric level variation at different points within the Souss-Massa aquifers (ABHSM 2015), b Annual variation of precipitation in three main meteorological stations (Agadir, Taroudant and Aoulouz) in the Souss-Massa Basin (Hsaissoune et al. 2016)

\subsection{Quality of groundwater}

The Moroccan national system for the assessment of groundwater quality considers 6 indicative parameters of the physic-chemical, organic, nitrogen and bacterial pollution. The table 1 shows the different parameters that determine water quality and rank them according to their quality from very poor to excellent.

Table 1 Simplified grid for the assessment of the overall quality of groundwater (SEEE 2014) 


\begin{tabular}{|l|l|l|l|l|l|l|}
\hline $\begin{array}{l}\text { Quality } \\
\text { parameters }\end{array}$ & $\begin{array}{l}\text { Electrical } \\
\text { Conductivity } \\
(\mu \mathrm{s} / \mathrm{cm})\end{array}$ & $\begin{array}{l}\text { Chloride } \\
\mathrm{Cl}^{-} \\
(\mathrm{mg} / \mathrm{l})\end{array}$ & $\begin{array}{l}\text { Nitrate } \\
\mathrm{NO}_{3}{ }^{-} \\
(\mathrm{mg} / \mathrm{l})\end{array}$ & $\begin{array}{l}\text { Ammonia } \\
\text { Nitrogen } \\
\mathrm{NH}_{4}{ }^{+} \\
(\mathrm{mg} / \mathrm{l})\end{array}$ & $\begin{array}{l}\text { Oxidizable } \\
\text { Matter } \\
\mathrm{MO} \\
(\mathrm{mg} / \mathrm{l})\end{array}$ & $\begin{array}{l}\text { Fecal } \\
\text { Coliform } \\
(\text { UFC/100ml })\end{array}$ \\
\hline Excellent & $<400$ & $<200$ & $<5$ & $\leq 0.1$ & $<3$ & $\leq 20$ \\
\hline Good & $400-1300$ & $200-300$ & $5-25$ & $0.1-0.5$ & $3-5$ & $20-2000$ \\
\hline Medium & $1300-2700$ & $300-750$ & $25-50$ & $0.5-2$ & $5-8$ & $2000-20000$ \\
\hline Bad & $2700-3000$ & $\begin{array}{l}750- \\
1000\end{array}$ & $50-100$ & $2-8$ & $>8$ & $>20000$ \\
\hline Very Bad & $>3000$ & $>1000$ & $>100$ & $>8$ & & - \\
\hline
\end{tabular}

Table 2 summarizes the average value of the physic-chemical and bacteriological analyses results of the water samples carried out in the three aquifers of the Souss-Massa region. These analyses were achieved by the Souss-Massa Hydraulic Basin Agency (ABHSM) from February 2014 to January 2015.

Table 2 Results of the physic-chemical and bacteriological analyses in the aquifers (ABHSM 2015)

\begin{tabular}{|l|l|l|l|l|l|l|}
\hline Aquifer & $\begin{array}{l}\text { Electrical } \\
\text { Conductivity } \\
(\mu \mathrm{s} / \mathrm{cm})\end{array}$ & $\begin{array}{l}\mathrm{Cl}^{-} \\
(\mathrm{mg} / \mathrm{l})\end{array}$ & $\begin{array}{l}\mathrm{NO}_{3}^{-} \\
(\mathrm{mg} / \mathrm{l})\end{array}$ & $\begin{array}{l}\mathrm{NH}_{4}{ }^{+} \\
(\mathrm{mg} / \mathrm{l})\end{array}$ & $\begin{array}{l}\text { Oxidizable } \\
\text { Matter } \\
(\mathrm{mg} / \mathrm{l})\end{array}$ & $\begin{array}{l}\text { Fecal coliform } \\
(\mathrm{UFC} / 100 \mathrm{ml})\end{array}$ \\
\hline Souss & 1086 & 161.02 & 8.4 & 0.2355 & 1.81 & 21 \\
\hline Chtouka & 1589 & 288.61 & 30.5 & 0.1522 & 2.05 & 14 \\
\hline Tiznit & 1007 & 108.02 & 28.2 & 0.0272 & 1.83 & 0 \\
\hline
\end{tabular}

The results in the study area indicate that nitrate contents in groundwater vary widely in the space (Table 2). The values range from $0.015 \mathrm{mg} / \mathrm{l}$ to $124.95 \mathrm{mg} / \mathrm{l}$ with an average of $22.37 \mathrm{mg} / \mathrm{l}$ (ABHSM 2015). The spatial distribution of nitrate concentrations shows that areas highly polluted by nitrates are located in the Chtouka Ait Baha, Massa and Tiznit. Other areas appear to be spared from nitrate pollution. Nitrate levels in this sectors remain in compliance with the drinking water standard of $50 \mathrm{mg} / \mathrm{l}$. Anthropogenic activities, and in particular agriculture, are the major factors that accentuate the process of water pollution by nitrates. Indeed, groundwater, are currently threatened by the abusive use of nitrogen fertilizers (Tagma et al. 2009).

In the Souss-Massa basins, the average ammonia nitrogen content in groundwater is $0.138 \mathrm{mg} / \mathrm{l}$ with a maximum value of $1.65 \mathrm{mg} / \mathrm{l}$ in Souss downstream and a minimum value of $0.001 \mathrm{mg} / \mathrm{l}$ recorded in the Souss upstream. The distribution of groundwater quality by ammoniacal nitrogen class in the Souss-Massa aquifers shows that in general Souss and Tiznit aquifers are in good quality on the contrary to Chtouka aquifer (ABHSM 2015 and Malki et al. 2016).

The hydrochemical data shows a spatial variation of chloride. The results of the analyses show that anomalies (value $>1000 \mathrm{mg} / \mathrm{l}$ ) occur in the Chtouka plain. Indeed, the Souss and Tiznit aquifers contain waters of good to medium chemical quality where the concentration of chloride does not exceed $700 \mathrm{mg} / \mathrm{l}$. The results of measure for electrical conductivity show that along the shore the values are high except at in the dune sector located to the South of the Oued Souss. Thus we distinguish: (i) an average value of 1086 $\mu \mathrm{S} / \mathrm{cm}$ in the Souss aquifer; (ii) an average value of $1589 \mu \mathrm{S} / \mathrm{cm}$ in the Chtouka aquifer; (iii) an average value of $1007 \mu \mathrm{S} / \mathrm{cm}$ in the Tiznit aquifer (ABHSM 2015). These salinity anomalies have multiple origins such as: (i) marine intrusion due to frequent and 
intensive pumping during drought periods which cause the drop of the groundwater level and a possible rise of the saline bevel to the lands; (ii) the geological formations of aquifers which are rich in evaporite and schist (Bouchaou et al. 2008).

Regarding oxidizable materials and fecal coliforms, analytical results show that in general groundwater is good to excellent quality. The overall quality of groundwater in the Souss-Massa region seems that the Souss aquifer is characterized by good quality unlike the Chtouka and Tiznit aquifer (Fig. 3).

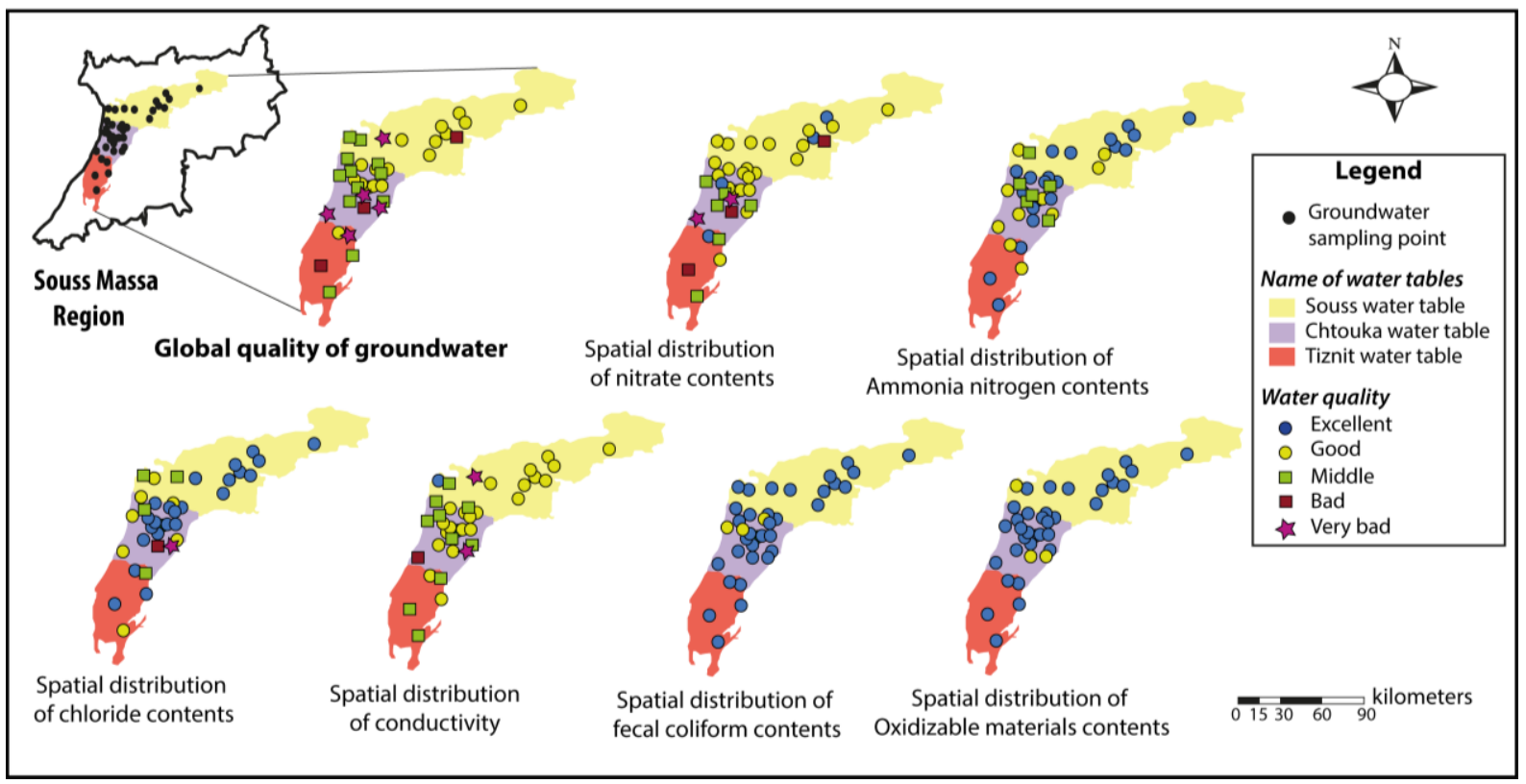

Fig. 3 Global water quality of Souss-Massa aquifers according to the sampling campaign results by the ABHSM from February 2014 to January 2015

\section{Discussion}

The Souss-Massa region is an important agricultural and touristic pole in the country. As a result, the Souss-Massa region is now confronted with multiple constraints such as overexploitation of aquifers, high population growth and water resources pollution. Accordingly, it is necessary a good management of water resources. The region is characterized by intensive agriculture, which is mainly based on irrigation and consumes more than $90 \%$ of water resources. The continuous extraction of groundwater decreases the groundwater level, and the use of deep wells and drilling is mandatory. The water resources become limited, therefore more expensive to extract and can rise to 0.13 Euro $/ \mathrm{m}^{3}$. By way of comparison, the cost of pumping is higher than that of wastewater treatment (ABHSM 2006).

Agriculture remains the country's largest source of employment. Intensive use of groundwater for irrigation will have a huge impact on farmland. The decline in agricultural profitability and the quality of products are among the consequences of this deterioration of water resources. According to recent studies, a decrease of $8 \%$ in the added value of the agricultural sector in the Souss-Massa region will be due to this water stress (Elame and Doukkali 2012). On this basis, farmers' incomes will decline, especially 
small farmers who are most dominant and unable to bear the cost of lowering water levels. In addition, rural unemployment will increase and this will encourage migration. This leads to the abandonment of agricultural land, as in the case of Sebt el Guerdane, Taroudant, Ouled Teima and Chtouka. Groundwater also plays an essential role in maintaining ecosystems in arid regions. In the Chtouka Ait Baha province, all ecosystems (agroecosystems, wetlands, forests, etc.), depend on groundwater for their continuity. These ecosystems have a great impact on the socio-economic development of the region and provide valuable services to humans and other species. These systems are of great value because they support high biodiversity, produce diverse agricultural foods and provide habitat for several rare and endangered animal species. This water stress experienced by the region will have adverse effects on groundwater ecosystems (Hirich et al. 2016).

The combined use of groundwater and surface water should be devoted to the supply drinking water, and agriculture should make greater use of treated wastewater. The development of the wastewater treatment field, whether physical, chemical or biological pathways, allow to have water which can be reused in agriculture and it is in accordance with irrigation standards. Our next research will focus on the development of an integrated set of technological tools and management systems to improve wastewater treatment and reuse of treated wastewater for irrigation, in order to reduce the water stress in the Souss-Massa region. Various wastewater treatment technologies are developed and adapted to the local context. Among these processes: (i) Lagoon piped with nitrification/denitrification and disinfection capacity: these lagoons are characterized by alternating aerobic and anoxic zones, making them suitable for the nitrification/denitrification process and biological removal of BOD (Biological oxygen demand) and phosphorus. (ii) Innovative nitrifying percolator filters with high surface area: in the case of small and medium-sized communities, nitrifying percolator filters can be an attractive alternative to activate sludge units, due to the low energy consumption required for waste water aeration. We will develop filters characterized by innovative high surface area to reduce retention time by biofilm of substantial thickness, and to improve the nitrification/denitrification performance. (iii) Artificial marshes with bacteria promoting plant growth: artificial marshes have the potential to eliminate nitrogen, phosphorus, heavy metals and residual BOD due to the combined effect of plants and the microbial community of the rhizosphere. Bacteria that promote plant growth can play a key role in artificial swamps by actively acting with plants in the process of degradation. (iv) Disinfection of wastewater by catalytic beds activated by solar UV radiation: this technique is a low cost, low environmental impact technology and can be an effective alternative to conventional disinfection systems. The effluent stored in a tank at night, will be treated during the day. (v) Integrated flotation/flocculation process: flotation is an attractive alternative to sedimentation due to reduced treatment volumes and increased treatment efficiency. The proposed process leads to higher purification efficiencies not only in terms of suspended solids but also in terms of BOD. This technique is characterized by a very low hydraulic retention time and low recycling rate. All these technologies are designed for different types of wastewater (urban, industrial, etc.) and will be tested on a pilot scale in the laboratory to check their effectiveness before applying them on a large scale.

\section{Conclusion}


Water resources in Souss-Massa region are overexploited. Also, the area is exposed to frequent droughts and scarcity of precipitation. This produces significant water stress in the region, which requires good governance of water resources. Without forgetting that, human factors specifically the development in the sectors of industry, tourism and agriculture which is a major consumer of water, play an important role in the degradation of these resources. Rain fed crops will be most affected by drought and arid climate. Irrigated crops will also be affected due to the reduction in the quantity of mobilized water resources. Consequently, all development activities will be constrained by the scarcity of water resources if no institutional strategy and appropriate management are applied. Integrated solutions for the treatment reuse and sustainable management of water resources in agriculture must be developed. This has become necessary in order to reduce the vulnerability of water resources and promoting sustainable agriculture, food security and economic growth.

Acknowledgements We would like to thank of ABHSM for their cooperation in providing all the necessary data. We are grateful to the project entitled MADFORWATER for its financial support of this research.

\section{References}

ABHSM (2006) Agence du Bassin Hydraulique du Souss-Massa. Etude de révision du plan directeur d'aménagement intégré des ressources en eau (PDAIRE) des bassins du Souss-Massa. Volume 10: Demande en eau agricole, Juin 2006

ABHSM (2015) Agence du Bassin Hydraulique du Souss-Massa. Etat de la qualité des ressources en eau dans les bassins hydrauliques de Souss-Massa et Drâa, Janvier 2015

Bouchaou L, Michelot J.L, Vengosh A, Hsissou Y, Qurtobi M, Gaye C.B, Bullen T.D, Zuppi G.M (2008) Application of multiple isotopic and geochemical tracers for investigation of recharge, salinization, and residence time of water in the Souss-Massa aquifer, Southwest of Morocco. Journal of Hydrology 352:267-287

Bouchaou L, Tagma T, Boutaleb S, Hssaisoune M, El Morjani Z (2012) Climate change and its impacts on groundwater resources in Morocco: the case of the Souss-Massa basin. Climate change effects on groundwater resources: a global synthesis of findings and recommendations. International Association of Hydrogeologists 27:129-144

Elame F, Doukkali R (2012) Water Valuation in Agriculture in the Souss-Massa Basin (Morocco). In: Choukr-Allah R, Ragab R, Rodriguez-Clemente R (eds) Integrated Water Resources Management in the Mediterranean Region, Springer Science+Business Media Dordrecht, Netherlands, p 109-122

Haddouch M, Elame F, Abahous H, Choukr-Allah R (2016) Socio-Economics and Governance of Water Resources in the Souss-Massa River Basin. In: Choukr-Allah R, Ragab R, Bouchaou L, Barceló D (eds) The Souss-Massa River Basin, Morocco, Springer International Publishing, Switzerland, p 335-350

Hirich A, Choukr-Allah R, Nrhira A (2016): Groundwater-Dependent Ecosystems in the Souss-Massa River Region: An Economic Valuation of Ecosystem Services. In: Choukr-Allah R, Ragab R, Bouchaou L, Barceló D (eds) The Souss-Massa River Basin, Morocco, Springer International Publishing, Switzerland, p 163-196 
Hsaissoune M, Boutaleb S, Benssaou M, Bouchaou L (2016) Physical Geography, Geology, and Water Resource Availability of the Souss-Massa River Basin. In: Choukr-Allah R, Ragab R, Bouchaou L, Barceló D (eds) The Souss-Massa River Basin, Morocco, Springer International Publishing, Switzerland, p 27-56

Malki M, Choukr-Allah R, Bouchaou L, Ait Brahim Y, Hirich A, Reichert B (2016) Evolution of groundwater quality in intensive agricultural zone: Case Of ChtoukaMassa Aquifer, Morocco. Arabian Journal of Geosciences 9:566

SEEE (2014) Fiche sur le nouveau système d'évaluation de la qualité des eaux, Maroc. Secrétariat d'état auprès du ministère de l'Energie des Mines, l'Eau et de l'Environnement, Juin 2014

Seif-Ennasr M, Zaaboul R, Hirich A, Caroletti G.N, Bouchaou L, El Morjani Z, Beraaouz H, Rachael A, Choukr-Allah R (2016) Climate change and adaptive water management measures in Chtouka Aït Baha region (Morocco). Science of the Total Environment 573:862-875

Tagma T, Hsissou Y, Bouchaou L, Bouragba L, Boutaleb S (2009) Groundwater nitrate pollution in Souss-Massa basin (Southwest Morocco). African Journal of Environmental Science and Technology 9: 301-309

WWDR (2016) Water and Jobs. The United Nations World Water Development Report. Annual report 